\title{
Effect of Various Cutting Management Schedule in Oat Crop
}

\author{
Priti Malik* and Babli
}

Department of Agronomy, CCS Haryana Agricultural University, Hisar- 125004, Haryana, India

*Corresponding author

\section{A B S T R A C T}

\begin{tabular}{|l|}
\hline Keyw or d s \\
Cutting \\
management, Plant \\
height, Test weight, \\
Grain, Yield. \\
\hline Article Info \\
\hline $\begin{array}{l}\text { Accepted: } \\
\text { 07 October } 2017 \\
\text { Available Online: } \\
\text { 10 December } 2017\end{array}$ \\
\hline
\end{tabular}

Results obtained from the field experiment on oat crop indicated that highest fodder yield was recorded when crop was cut at 70 days after sowing (DAS) followed by cut at 60 DAS and least by 50 DAS. Highest grain yield was recorded when oat was cut at 60 DAS (28.06 $\left.\mathrm{q} \mathrm{ha}^{-1}\right)$ followed by cut at 50 DAS $\left(25.57 \mathrm{q} \mathrm{ha}^{-1}\right)$ and lowest by cut at 70 DAS (23.93 q $\mathrm{ha}^{-1}$ ). However, straw yield was recorded maximum under treatment cut at 50 DAS (65.46 $\left.\mathrm{q} \mathrm{ha}^{-1}\right)$ followed by at $60\left(63.68 \mathrm{q} \mathrm{ha}^{-1}\right)$ and least at $70\left(55.40 \mathrm{q} \mathrm{ha}^{-1}\right)$. Crude protein in fodder decreased significantly with increase in age of crop and decrease was from 13.51 per cent at cut at 50 DAS to 12.64 per cent 12.51 at cut 60 DAS and 11.77 at cut at 70 DAS. Maximum plant height was recorded when oat was cut at 70 DAS (65.9) followed by cut at 60 DAS (53.8) and then cut at 50 DAS (45.9). Highest green fodder and dry matter accumulation were recorded when oat was cut at 70 DAS (172.6 and 34.4q/ha) and least when oat was cut at 50 DAS (140.2 and 22.8q/ha). Seeds per panicle were found highest (66.0) under first cut and lowest at third cut for fodder 62.20 grains/panicle. The test weight of oat was found highest (39.23) with the 60 DAS and it was significantly higher over 50 and 70 DAS.

\section{Introduction}

Forages are the main stay of animal wealth and their production is the backbone of livestock industry. The scarcity of green forages and grazing resources in the country has made the livestock to suffer continuously with malnutrition resulting in their production potentiality at sub optimum level as compared to other countries. Oat is one of the most important rabi season fodder crop in India and used both feeds and fodder. To study the effect of cutting management on growth and yield in oat, experiment was conducted at the Forage research farm of CCSHAU, Hisar during rabi 2012-13. Oat var. HJ 8 was taken as test crop. Hisar is situated in the semi-arid, sub tropics at $29^{0} 17^{\prime} \mathrm{N}$ latitude and $75^{\circ} 77^{\prime} \mathrm{E}$ longitude at an altitude of $215.2 \mathrm{~m}$ above msl. The soil of the field is derived from IndoGangetic alluvium and is sandy loam in texture. Three cuttings $\left(\mathrm{C}_{50}=\right.$ first cut 50 DAS, $\mathrm{C}_{60}=$ second cut 60 DAS and $\mathrm{C}_{70}=$ third cut 70 DAS) were maintained.

Digestible dry matter was higher under single cut than in two cut system. He also stated that concentration of nitrogen was highest when no cutting was done (Deorari, 2002). Among cutting managements, except at first cut, single cut recorded maximum dry matter accumulation through leaf and stem at all stages while at first cut stage, cutting at 70 days after sowing recorded maximum 
accumulation through leaf and stem. He also reported that digestible dry matter yield was higher under single cutting management than in two cutting management. However, dry matter digestibility was higher when first cut taken at 50 days after sowing and second cut at 50 percent flowering stage (Singh, 2004).

Single cut at $50 \%$ flowering recorded significantly higher dry-matter $(8.05 \mathrm{t} / \mathrm{ha})$ and digestible dry-matter yield (5.0 t/ha), drymatter content $(20.85 \%)$, acid-detergent fibre (48.14\%), neutral detergent fibre $(59.56 \%)$ and hemicellulose content $(23.02 \%)$ than double-cutting system but total crude-protein yield $(805 \mathrm{~kg} / \mathrm{ha})$, crude-protein content at both the cuts $(18.70$ and $10.55 \%$ respectively), digestibility (76.31\%), ash $(10.44 \%)$ and cell contents $(56.79 \%)$ at the first cut were significantly higher when the first cut was taken at 50 days after sowing and the second cut at $50 \%$ flowering. However, at second cut, digestibility (66.72\%), ash $(10.34 \%)$ and cell contents $(43.47 \%)$ were statistically higher when the first cut was taken at 60 days after sowing and the second cut at $50 \%$ flowering (Bhilare and Joshi, 2007).

Among cutting management practices, no cut treatment produced higher seed (2.33 t/ha) and straw (11.05 t/ha) yields than cutting at 30 and 45 DAS. However, highest green fodder yield (14.38 $\mathrm{t} / \mathrm{ha}$ ) was recorded with cutting at 45 DAS (Patel et al., 2011). Double cut crop recorded 14.75 and $16.24 \%$ increase in green fodder yield and 3.70 and $1.36 \%$ in dry fodder yield over single cut crop during 2009-10 and 2010-11, respectively. Moreover, double cut crop recorded higher crude protein content but lower crude fibre content (Jehangir et al., 2013).

The treatment combination consisting of cutting management, one at 60 days after sowing and the other at 50 per cent flowering along with $80 \mathrm{~kg} \mathrm{~N} / \mathrm{ha}$ applied 50 per cent basal and 50 per cent as top dressing after first cut recorded the highest green fodder and dry matter yield (Suhrawardy and Kalita, 2001). Increasing levels of phosphorus fertilizer application did not increase dry matter content of oat fodder significantly, however, in second cutting, a significant difference was observed in dry matter content of oat fodder (Mohiuddin, 2002). Application of Nitrogen $75 \mathrm{~kg} / \mathrm{ha}$ and Phosphorus $40 \mathrm{~kg} / \mathrm{ha}+$ inoculation of seed with Azotobacter produced highest seed and stover yield. No cut produced higher seed yield than cutting managements (Singh et al., 2005).

Fertility treatments $\mathrm{F}_{3} \quad\left(\mathrm{~N}_{75}+\mathrm{P}_{40} \mathrm{~kg} / \mathrm{ha}+\right.$ Azotobacter inoculation) and $\mathrm{F}_{4}\left(\mathrm{~N}_{100}+\mathrm{P}_{60}\right.$ $\mathrm{kg} / \mathrm{ha}$ ) being at par produced significantly higher seed yield. No cut treatment had produced statistically higher seed yield than other cutting treatments (Karwasra et al., 2007).

Among cutting managements, crop harvested once at 50 per cent flowering $\left(\mathrm{C}_{1}\right)$ significantly improved leaf area index, specific leaf weight and also the dry matter yield. Leaf area index significantly increased with increase in nitrogen levels up to $160 \mathrm{~kg}$ $\mathrm{ha}^{-1}$ and dry matter yield up to $120 \mathrm{~kg} \mathrm{~N} \mathrm{ha}^{-1}$ (Bhilare, 2009).

Application of $25 \%$ higher dose of $\mathrm{N} \& \mathrm{P}$ fertilizers than the recommended gives significantly higher seed yield. Likewise one cutting at 60 days after sowing, lodging could be reduced significantly whereas maximum seed yield was obtained with OS 6 as it showed maximum response to cutting and fertilizer management practices (Kumar and Dudi, 2010). Crude protein content increased with increase in fertility level up to $150 \mathrm{~kg} \mathrm{~N}$ $+70 \mathrm{~kg} \mathrm{P}_{2} \mathrm{O}_{5}+40 \mathrm{~kg} \mathrm{~K}_{2} \mathrm{O} \mathrm{ha}^{-1}$. Double cut crop gave higher forage yield and better quality traits as compared to single cut crop 
(Jehangir et al., 2012). Increasing trend was found in dry matter accumulation and leaf area index of oats with the advancement of growth of the crop up to 60 days when 1st cutting was taken. A significant response from cutting and fertilizer management was found on total green and dry fodder yields of oats. The highest green and dry fodder yields were achieved from fertilizer schedule of $\mathrm{N}_{120}, \mathrm{P}_{60}, \mathrm{~K}_{60} \mathrm{~kg} \mathrm{ha}^{-1}$ both at single cutting and two cuttings management. Significantly higher total green and dry fodder yields were obtained from two cut management (29.74 and $7.92 \mathrm{t} \mathrm{ha}^{-1}$, green and dry fodder respectively) when compared with single cut management (14.68 and $3.37 \mathrm{t} \mathrm{ha}^{-1}$, respectively), indicating the scope of getting two cuttings from fodder oats in red and lateritic belt of West Bengal (Hedayetullah and Barik, 2012).

The highest green forage yield, crude protein yield, and neutral detergent fibre yield were obtained with the application of $\mathrm{N}$ in 3 splits $(1 / 2$ of the total rate as basal $+1 / 4$ of the total rate at $20 \mathrm{DAS}+1 / 4$ of the total rate at 40 DAS) along with the application of $K$ in 2 splits $(1 / 2$ of the total rate as basal $+1 / 2$ of the total rate at 20 DAS) under double cutting (Alipatra et al., 2013).

The genotype JHO 99-2 recorded significantly higher green forage $\left(37.71 \mathrm{t} \mathrm{ha}^{-1}\right)$ and dry matter yield $\left(7.45 \mathrm{tha}^{-1}\right)$ compared to JHO 822 and Kent. The nitrogen level of 150 $\mathrm{kg} \mathrm{N}$ ha ${ }^{-1}$ produced significantly higher green forage (39.41 $\left.\mathrm{t} \mathrm{ha}^{-1}\right)$ and dry matter yield $\left(7.79 \mathrm{t} \mathrm{ha}^{-1}\right)$ compared to 120 and $90 \mathrm{~kg} \mathrm{~N}$ $\mathrm{ha}^{-1}$. Harvesting of fodder at 65 DAS recorded significantly higher green forage $(35.39 \mathrm{t}$ $\left.\mathrm{ha}^{-1}\right)$ and dry matter yield (7.19 $\left.\mathrm{t} \mathrm{ha} \mathrm{ha}^{-1}\right)$ compared to 55 DAS. In interaction significantly higher green forage (46.92 $\left.\mathrm{t} \mathrm{ha}^{-1}\right)$ and dry matter yield $\left(8.64 \mathrm{t} \mathrm{ha}^{-1}\right)$ was obtained with genotype JHO 99-2 with $150 \mathrm{~kg} \mathrm{~N}^{-1}$ with cutting interval of 65 DAS (Patel and
Alagundagi, 2013). Based on finding it may be concluded that for taking fodder from first cut and grain from second cut, oats should be harvested for fodder at 60 days after sowing and then left for grain production. This practice provides good quality green fodder and maximum net returns.

\section{References}

Alipatra A, Kundu CK, Mandal MK, Banerjee $\mathrm{H}$ and Bandopadhyay P 2013. Yield and quality improvement in fodder oats (Avena sativa L.) through split application of fertilizer and cutting management. Journal of Crop and Weed 9(2): 193-195.

Bhilare RL 2009. Physiological basis of yield variation in oat in relation to nitrogen levels under different cutting management. Journal of Maharashtra Agricultural Universities, 34(2): 164167.

Bhilare RL and Joshi YP 2007. Productivity and quality of oat (Avena sativa) in relation to cutting management and nitrogen levels. Indian Journal of Agronomy, 52(3): 247-250.

Deorari V 2002. Studies on growth and seed yield of promising oat (Avena sativa) genotypes under varying levels of nitrogen. Thesis. M.Sc. G.B. Pant University of Agriculture and Technology, Pantnagar.

Hedayetullah M and Barik AK 2012. Influence of Cutting and Fertilizer Management on growth and yield of fodder oats. Madras Agriculture Journal 99 (10-12): 711-714.

Jehangir IA, Khan HU, Khan MH, Rasool FU, Bhat RA, Mubarak T, Bhat MA and Rasool S 2013. Effect of sowing dates, fertility levels and cutting managements on growth, yield and quality of oats. African Journal of Agricultural Research, 8(7): 648-651. 
Jehangir IA, Khan HU, Rasool F and Mahdi SS 2012. Yield and quality of fodder oat (Avena sativa L.) as influenced by sowing dates, fertility levels and cutting management. Applied Biological Research, 14(2): 164-167.

Karwasra RS, Kumar Y, Kumar V and Kumar A 2007. Integrated nutrient and cutting management in oat. Forage Research, 33(1): 63-64.

Kumar A and Dudi H 2010. Response of cutting and fertilizer management on quality seed production in oat (Avena sativa L.). Forage Research, 35(4): 246247.

Mohiuddin M 2002. Response of stage of maturity, different levels of nitrogen and phosphorus fertilizer on yield, nutritive value and mineral content of oat. M.Sc. Thesis. Department of Animal Nutrition, Bangladesh Agricultural University, Mymensingh.

Patel PA and Alagundagi SC 2013. Effect of Nitrogen Level and Cutting Interval on
Fodder Yield of Oat Genotypes. Trends in Bioscience, 6(6): 811-814.

Patel TU, Arvadia MK, Malik PK, Patel D D and Patel PS 2011. Productivity of oat (Avena sativa) under different cutting management and split application of nitrogen. Indian J. Agro, 56(2): 164167.

Singh H 2004. Effect of cutting management on forage yield and quality of oat (Avena sativa) varieties. Thesis. M.Sc. G.B. Pant University of Agriculture and Technology, Pantnagar.

Singh VP, Verma SS and Chandra R 2005. Effect of fertility levels with biofertilizers and cutting management on seed yield of oats. Forage Research 31(1): 57-58.

Suhrawardy J and Kalita U 2001. Effect of cutting management and nitrogen fertilization on fodder yield of rainfed oat (Avena sativa). Forage Research, 27(3): 185-188.

\section{How to cite this article:}

Priti Malik and Babli. 2017. Effect of Various Cutting Management Schedule in Oat Crop. Int.J.Curr.Microbiol.App.Sci. 6(12): 843-846. doi: https://doi.org/10.20546/ijcmas.2017.612.090 